\title{
Sex difference in kidney electrolyte transport III: Impact of low K intake on thiazide-sensitive cation excretion in male and female mice
}

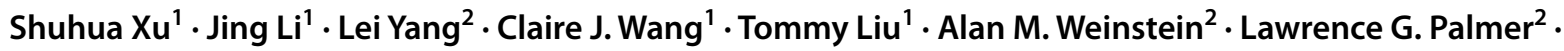 \\ Tong Wang ${ }^{1} \mathbb{D}$
}

Received: 27 April 2021 / Revised: 15 July 2021 / Accepted: 1 August 2021 /Published online: 29 August 2021

(c) The Author(s) 2021

\begin{abstract}
We compared the regulation of the $\mathrm{NaCl}$ cotransporter (NCC) in adaptation to a low-K (LK) diet in male and female mice. We measured hydrochlorothiazide (HCTZ)-induced changes in urine volume (UV), glomerular filtration rate (GFR), absolute (ENa, EK), and fractional (FENa, FEK) excretion in male and female mice on control-K (CK, $1 \% \mathrm{KCl})$ and LK $(0.1 \%$ $\mathrm{KCl}$ ) diets for 7 days. With CK, NCC-dependent ENa and FENa were larger in females than males as observed previously. However, with LK, HCTZ-induced ENa and FENa increased in males but not in females, abolishing the sex differences in NCC function as observed in CK group. Despite large diuretic and natriuretic responses to HCTZ, EK was only slightly increased in response to the drug when animals were on LK. This suggests that the K-secretory apparatus in the distal nephron is strongly suppressed under these conditions. We also examined LK-induced changes in Na transport protein expression by Western blotting. Under CK conditions females expressed more NCC protein, as previously reported. LK doubled both total (tNCC) and phosphorylated NCC (pNCC) abundance in males but had more modest effects in females. The larger effect in males abolished the sex-dependence of NCC expression, consistent with the measurements of function by renal clearance. LK intake did not change NHE3, NHE2, or NKCC2 expression, but reduced the amount of the cleaved (presumably active) form of $\gamma \mathrm{ENaC}$. LK reduced plasma $\mathrm{K}$ to lower levels in females than males. These results indicated that males had a stronger NCC-mediated adaptation to LK intake than females.
\end{abstract}

Keywords $\mathrm{Na}$ and $\mathrm{K}$ homeostasis $\cdot$ Renal clearance $\cdot \mathrm{NCC} \cdot \mathrm{HCTZ} \cdot \mathrm{ENaC}$ expression

\section{Introduction}

The thiazide sensitive Na-Cl co-transporter (NCC) is the major transporter for sodium and chloride reabsorption in the distal convoluted tubule (DCT) $(8,15,21,31)$. NCC activity is regulated by the level of the total protein expression, the amount of protein at the apical membrane, and also by phosphorylation or dephosphorylation of NCC, modulating uptake of $\mathrm{Na}^{+}$and $\mathrm{Cl}^{-}$in the DCT (24).

Shuhua $\mathrm{Xu}$ and Jing Li are contributed equally to this work.

Tong Wang

tong.wang@yale.edu

1 Department of Cellular and Molecular Physiology, Yale School of Medicine University, 333 Cedar Street, P.O. Box 208026, New Haven, CT 06520-8026, USA

2 Department of Physiology and Biophysics, Weill Medical College of Cornell University, New York, NY, USA
Phosphorylation is mediated by WNK and SPAK pathways $(28,48)$, and is influenced by hormones including angiotensin II and vasopressin $(25,35)$, and by plasma $\left[\mathrm{K}^{+}\right](32,33)$. Variation of NCC activity is important to maintain normal electrolyte homeostasis under conditions of low or high dietary K intake (9). High K intake decreases NCC expression and activity, leading to reduction of $\mathrm{Na}$ and $\mathrm{Cl}$ absorption in the DCT and increasing $\mathrm{Na}^{+}$and fluid delivery to the distal nephron leading to stimulation of $\mathrm{K}^{+}$secretion $(30,33,36$, 37). In contrast, dietary restriction up-regulates NCC expression, increasing $\mathrm{NaCl}$ absorption in the DCT and reducing $\mathrm{K}^{+}$secretion in more distal segments $(11,39)$.

NCC expression and function are sex-dependent. Female rats express more NCC than males due at least in part to higher levels of female hormones $(29,38)$. Previously we reported that females had higher diuretic, natriuretic, and kaliuretic responses to hydrochlorothiazide (HCTZ) and higher NCC and pNCC abundance in mice (18). We also found a sex difference in the response to HK intake; NCC 
decreased more in females than in males, blunting the sexdependent differences (19). In this study, we examine the sex difference in adaptation to LK intake. Specifically, we assess LK-induced changes in NCC activity, along with LK induced changes in NCC, NHE3, NHE2, NKCC2, and ENaC abundance, comparing male and female mice.

\section{Methods and materials}

\section{Animals}

All work with mice was conducted according to an approved Institutional Animal Care and Use Committee-approved protocol at Yale School of Medicine. Mice C57BL/6 J were purchased from Jackson Lab (MI) and housed at the Yale University Animal Care facility in New Haven, CT. Male and female mice aged 16-20 weeks were matched among control and all experimental groups. Mice were maintained on a control $(1 \% \mathrm{KCl}, 0.4 \% \mathrm{NaCl})$ or $\mathrm{LK}(0.1 \% \mathrm{KCl}, 0.4 \%$ $\mathrm{NaCl}$ ) diet purchased from Harlan Teklad Laboratory (Madison, WI, USA) for 7 days. All mice had free access to tap water and were kept on a $12 \mathrm{~h} / 12 \mathrm{~h}$ day and night cycle at room temperature until the day of the experiment. Mice were anesthetized with intraperitoneal injection (100 to $150 \mathrm{mg} /$ $\mathrm{kg}$ body weight) of Inactin (Thiobutabarbital sodium salt hydrate, Sigma, St. Louis, MO) before experiments.

\section{Renal clearance and measurements}

Renal clearance protocols were similar to those methods described previously (3). Briefly, anesthetized mice were placed on a thermostatically controlled surgical table to maintain body temperature at $37^{\circ} \mathrm{C}$. After a tracheotomy, a carotid artery was cannulated with PE10 polyethylene tubing for arterial blood collections and a jugular vein was cannulated with PE10 for intravenous infusion and injection. The bladder was catheterized with PE50 connected to PE10 tubing for timed urine collections. After surgical preparation, $0.05 \mathrm{ml}$ of isotonic saline was administere by iv to replace surgical fluid loss. Subsequently, a priming dose of $0.1 \mathrm{mg}$ FITC-Inulin (Sigma, St. Louis, MO) in $0.05-\mathrm{ml}$ isotonic saline was given, and a maintenance dose of isotonic solution containing $2 \mathrm{mg} / \mathrm{ml}$ FITC-Inulin was infused at a rate of $0.41 \mathrm{ml} / \mathrm{h}$ throughout the experiment. After a 45-min equilibration period, urine collections were made every $30 \mathrm{~min}$. The first 2 collections (0-60 min) were used as the control period (baseline); then HCTZ (Sigma, St. Louis, MO) was administered by bolus injection of $30 \mathrm{mg} / \mathrm{kgBW}$ followed by 4 additional 30 -min urine collections. HCTZ was dissolved in normal saline at the concentration of $30 \mathrm{mg} /$ $\mathrm{ml}$ and administered in a volume of $1 \mathrm{ml} / \mathrm{kgBW}$. Data for only three collection periods after the HCTZ are plotted in Figs. 1, 2, 3, and 4 for clarity. Blood samples $(30 \mu \mathrm{l})$ were taken between two urine collections. Urine and
Fig. 1 Effect of LK intake on HCTZ-induced changes in urine volume (UV) and GFR in male (A and $\mathbf{C}$ ) and female (B and D) mice. HCTZ was given by iv bolus injection $(30 \mathrm{mg} / \mathrm{kg}$ ) after two 30-min baseline urine collections. Urine volume and GFR was monitored for $90 \mathrm{~min}$ after HCTZ administration. Data are presented as means $\pm \mathrm{SE}$. *: Significant difference from the baseline ( $n=6, P<0.05$, by one-way ANOVA test), ${ }^{\ddagger}$ : Significant difference between CK and LK groups $(n=6, P<0.05$, by one-way ANOVA test)
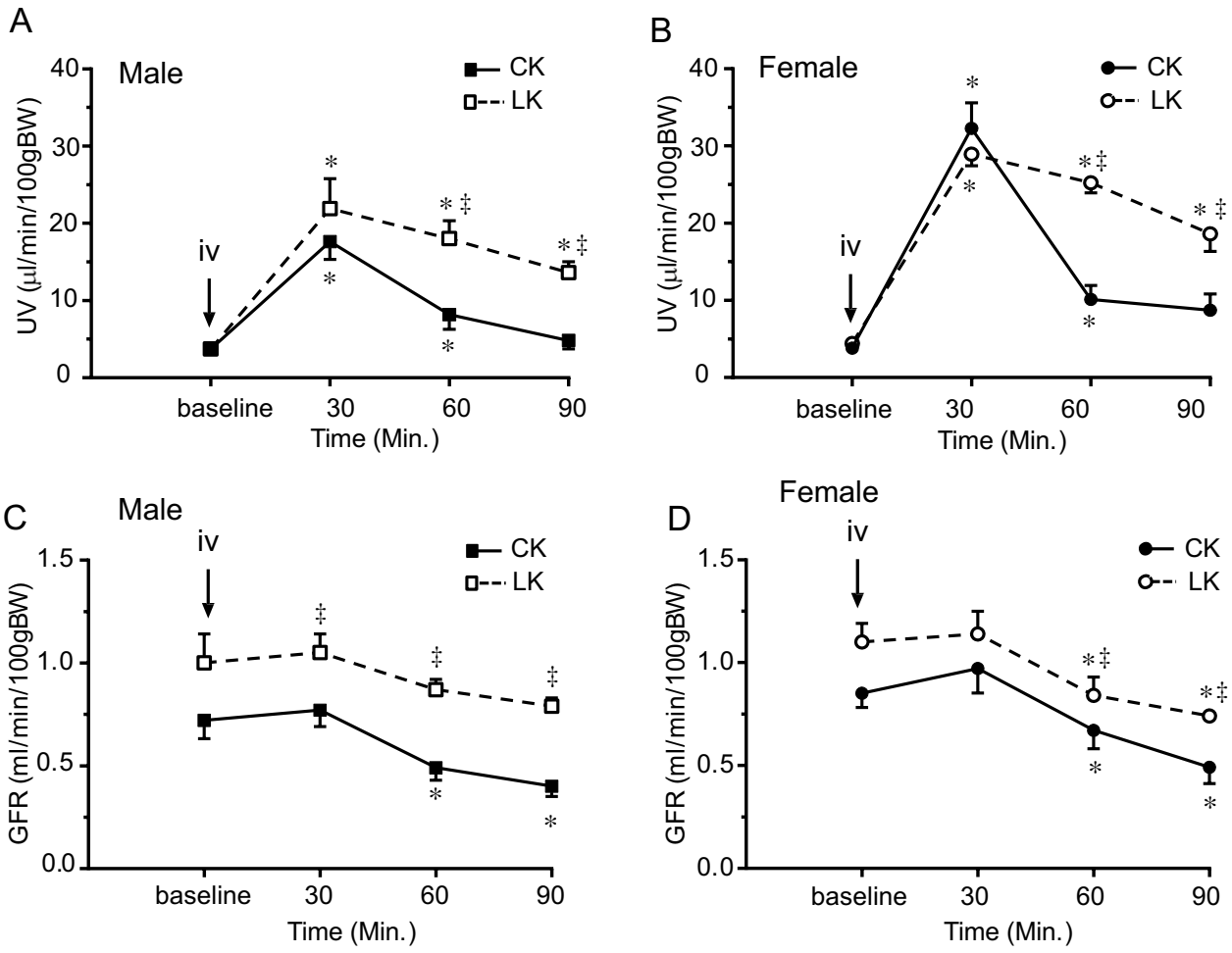

HCTZ-induced changes in absolute (ENa) and fractional (FENa) $\mathrm{Na}^{+}$excretion in male and female mice. HCTZ was given by iv bolus injection $(30 \mathrm{mg} / \mathrm{kg})$ after two 30 -min baseline urine collections. Urinary $\mathrm{Na}^{+}$excretion was monitored for $90 \mathrm{~min}$ after HCTZ administration. Data are presented as means $\pm \mathrm{SE}$. *: Significant difference from the baseline $(n=6, P<0.05$, by one-way ANOVA test), ${ }^{\ddagger}$ : Significant difference between CK and LK groups $(n=6, P<0.05$, by one-way ANOVA test)
Fig. 2 Effect of LK intake on
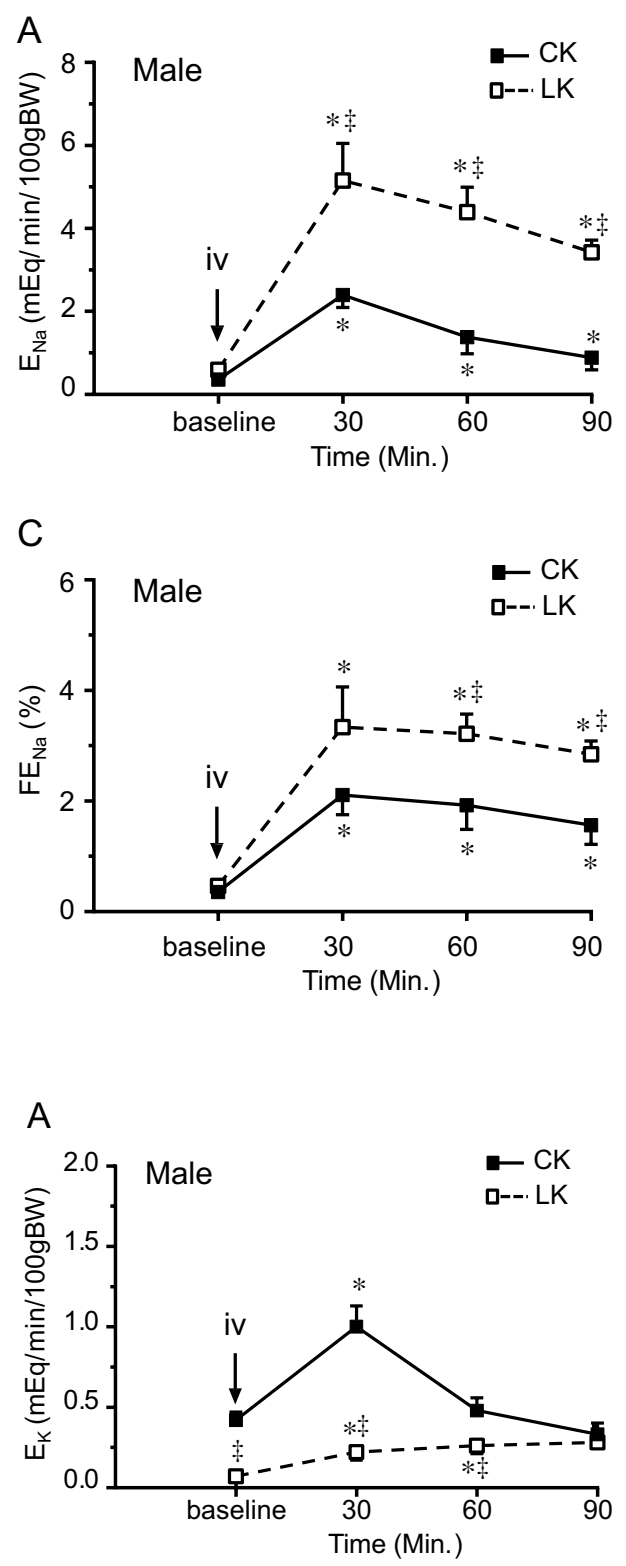

Fig. 3 Effect of LK intake on HCTZ-induced changes in absolute (EK) and fractional (FEK) $\mathrm{K}^{+}$excretion in male and female mice. HCTZ was given by iv bolus injection $(30 \mathrm{mg} / \mathrm{kg}$ ) after two 30-min baseline urine collections. Urinary $\mathrm{K}^{+}$excretion was monitored for $90 \mathrm{~min}$ after HCTZ administration. Data are presented as means $\pm \mathrm{SE}$. *: Significant difference from the baseline $(n=6, P<0.05$, by one-way ANOVA test), ${ }^{\ddagger}$ : Significant difference between $\mathrm{CK}$ and LK groups $(n=6, P<0.05$, by one-way ANOVA test)

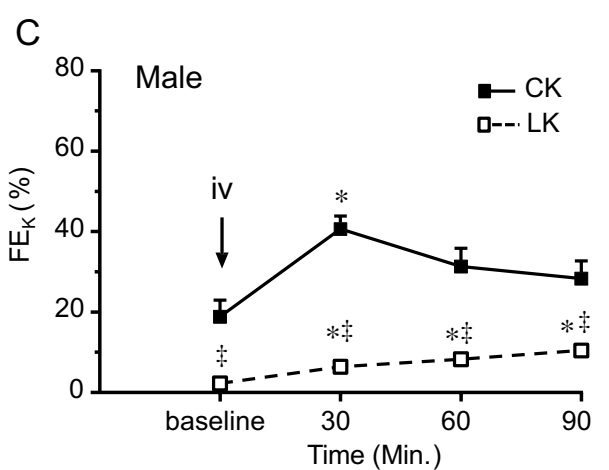

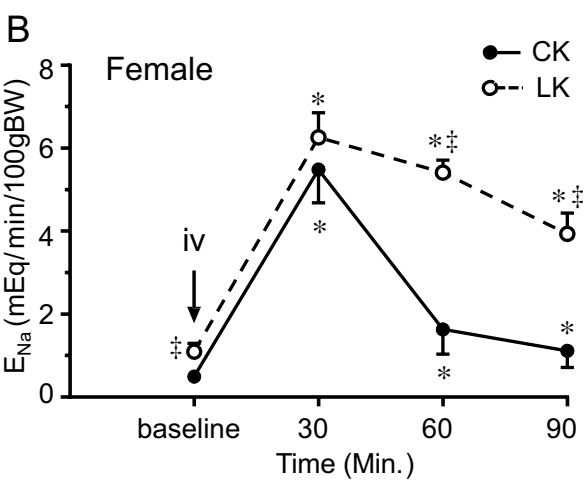
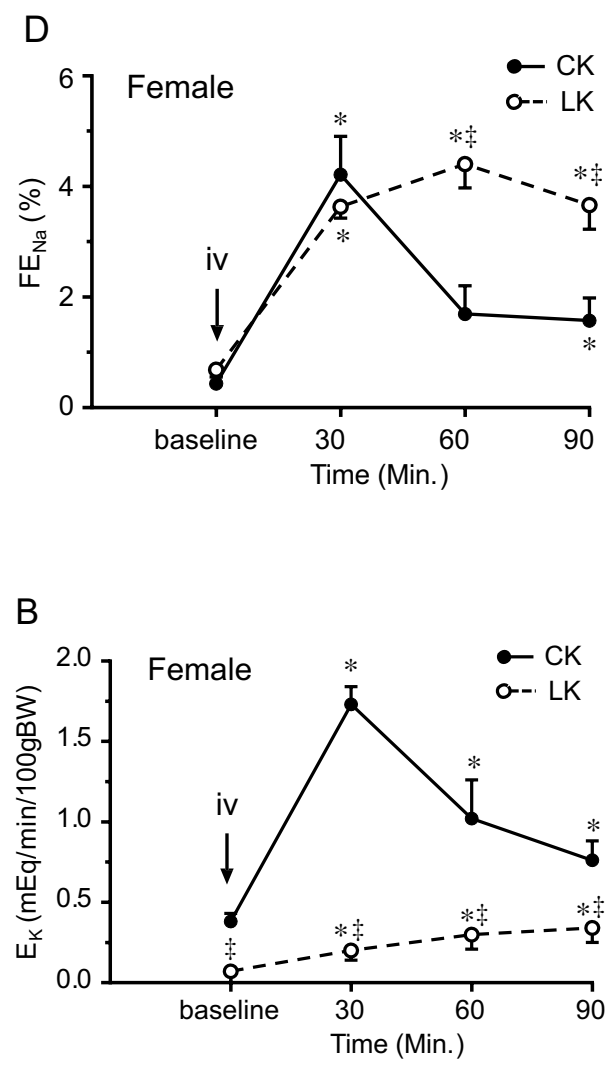

D

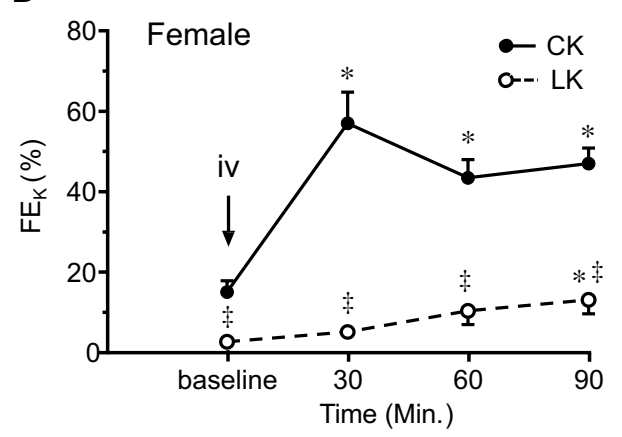

plasma $\mathrm{Na}^{+}$and $\mathrm{K}^{+}$concentrations were measured using a flame photometer (type 480, Corning Medical and Scientific, Corning, NY). FITC-Inulin concentrations were measured using a 96-plate reader. Urine volume (UV), glomerular filtration rate (GFR), absolute $\mathrm{Na}, \mathrm{K}$ (ENa, EK), and fractional $\mathrm{Na}, \mathrm{K}$ (FENa, FEK) were measured and calculated by standard methods (3). Renal clearance data are summarized in Tables 1 and 2. 
Table 1 Basal conditions of Control- $\mathrm{K}^{+}$diet and Low- $\mathrm{K}^{+}$ diet treated mice

\begin{tabular}{lllllll}
\hline Diet & Group & $n$ & $\mathrm{BW}(\mathrm{g})$ & $\mathrm{P}_{\mathrm{Na}}(\mathrm{mEq} / \mathrm{L})$ & $\mathrm{P}_{\mathrm{K}}(\mathrm{mEq} / \mathrm{L})$ & $\mathrm{HCT}, \%$ \\
\hline CK & Male & 7 & $33.5 \pm 1.3$ & $154.5 \pm 3.5$ & $4.1 \pm 0.2$ & $45.0 \pm 0.9$ \\
& Female & 6 & $28.1 \pm 1.7$ & $146.7 \pm 2.7$ & $3.8 \pm 0.2$ & $47.4 \pm 1.1$ \\
LK & Male & 6 & $29.7 \pm 1.3$ & $146.2 \pm 3.5$ & $3.3 \pm 0.2 *$ & $42.9 \pm 0.9$ \\
& Female & 6 & $21.7 \pm 0 . *^{\dagger}$ & $152.1 .3 \pm 7.0$ & $2.7 \pm 0 . *^{\dagger \dagger}$ & $46.4 \pm 1.6$ \\
\hline
\end{tabular}

Data are presented as means $\pm \mathrm{SE} ; n$, number of animals; $B W$ : body weight; $C K$, control- $\mathrm{K}^{+}$diet contains $1 \% \mathrm{KCl} ; L K$, low- $\mathrm{K}^{+}$diet contains $0.1 \% \mathrm{~K}^{+} ; P_{N a}$, plasma $\mathrm{Na}^{+} ; P_{K}$ : plasma $\mathrm{K}^{+} ; H C T$, hematocrit. *: Significant difference between $\mathrm{CK}$ and $\mathrm{LK}$ at same sex $(P<0.05)$; ${ }^{\dagger}$ Significant difference between male and female in the same diet $(P<0.05)$

Table 2 Effects of hydrochlorothiazide on urine volume, glomerular filtration rate, $\mathrm{E}_{\mathrm{Na}}$, and $\mathrm{E}_{\mathrm{K}}$, in mice on the Control- $\mathrm{K}^{+}$and Low- $\mathrm{K}^{+}$diet

\begin{tabular}{|c|c|c|c|c|c|c|c|}
\hline & $\begin{array}{l}\mathrm{UV} \\
\left(\mu \mathrm{l} \cdot \min ^{-1}\right. \\
\left.100 \mathrm{~g} \mathrm{BW}^{-1}\right)\end{array}$ & 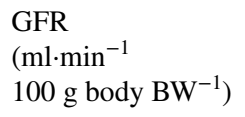 & $\begin{array}{l}\mathrm{E}_{\mathrm{Na}} \\
\left(\mu \mathrm{eq} \cdot \mathrm{min}^{-1}\right. \\
\left.100 \mathrm{~g} \text { body } \mathrm{BW}^{-1}\right)\end{array}$ & $\begin{array}{l}\mathrm{E}_{\mathrm{K}} \\
\left(\mu \mathrm{eq} \cdot \mathrm{min}^{-1}\right. \\
\left.100 \mathrm{~g} \text { body } \mathrm{BW}^{-1}\right)\end{array}$ & $\begin{array}{l}\mathrm{E}_{\mathrm{Na}}+\mathrm{E}_{\mathrm{K}} \\
\left(\mu \mathrm{eq} \cdot \min ^{-1}\right. \\
\left.100 \mathrm{~g} \text { body } \mathrm{BW}^{-1}\right)\end{array}$ & $\mathrm{E}_{\mathrm{K}} / \mathrm{E}_{\mathrm{Na}}+\mathrm{E}_{\mathrm{K}}$ & $\mathrm{E}_{\mathrm{Na}} / \mathrm{E}_{\mathrm{K}}$ \\
\hline & & & Control- $K^{+}$diet & & & & \\
\hline \multicolumn{8}{|c|}{ Male mice } \\
\hline Baseline & $3.7 \pm 0.4$ & $0.72 \pm 0.09$ & $0.36 \pm 0.1$ & $0.42 \pm 0.05$ & $0.78 \pm 0.1$ & $0.55 \pm 0.07$ & $1.01 \pm 0.3$ \\
\hline $0-30$ & $17.6 \pm 2.3^{*}$ & $0.77 \pm 0.08$ & $2.39 \pm 0.3 *$ & $1.00 \pm 0.13^{*}$ & $3.40 \pm 0.4^{*}$ & $0.31 \pm 0.03 *$ & $2.44 \pm 0.3^{*}$ \\
\hline $30-60$ & $8.2 \pm 1.9 *$ & $0.49 \pm 0.06$ & $1.38 \pm 0.4^{*}$ & $0.48 \pm 0.08$ & $1.86 \pm 0.4^{*}$ & $0.29 \pm 0.04 *$ & $2.87 \pm 0.5^{*}$ \\
\hline $60-90$ & $4.8 \pm 1.1$ & $0.40 \pm 0.05^{*}$ & $0.88 \pm 0.3^{*}$ & $0.33 \pm 0.07$ & $1.21 \pm 0.3$ & $0.31 \pm 0.07 *$ & $3.13 \pm 0.8^{*}$ \\
\hline $90-120$ & $3.4 \pm 0.5$ & $0.36 \pm 0.05^{*}$ & $0.63 \pm 0.1 *$ & $0.31 \pm 0.07$ & $0.93 \pm 0.2$ & $0.34 \pm 0.05^{*}$ & $2.45 \pm 0.6^{*}$ \\
\hline \multicolumn{8}{|c|}{ Female mice } \\
\hline Baseline & $3.8 \pm 0.6$ & $0.85 \pm 0.07$ & $0.49 \pm 0.1$ & $0.38 \pm 0.05$ & $0.87 \pm 0.1$ & $0.47 \pm 0.06$ & $1.42 \pm 0.4$ \\
\hline $0-30$ & $32.3 \pm 3.3 * \dagger$ & $0.97 \pm 0.12$ & $5.48 \pm 0.8^{* \dagger}$ & $1.73 \pm 0.11^{* \dagger}$ & $7.21 \pm 0.8 * \dagger$ & $0.26 \pm 0.03 *$ & $3.25 \pm 0.5^{*}$ \\
\hline $30-60$ & $10.1 \pm 1.8^{*}$ & $0.67 \pm 0.09$ & $1.63 \pm 0.6^{*}$ & $1.02 \pm 0.24 *$ & $2.65 \pm 0.7 *$ & $0.44 \pm 0.06$ & $1.65 \pm 0.4$ \\
\hline $60-90$ & $8.7 \pm 2.1$ & $0.49 \pm 0.08 *$ & $1.11 \pm 0.4^{*}$ & $0.76 \pm 0.12^{* \dagger}$ & $1.88 \pm 0.4$ & $0.46 \pm 0.05$ & $1.39 \pm 0.3$ \\
\hline \multirow[t]{2}{*}{$90-120$} & $6.9 \pm 1.1$ & $0.44 \pm 0.03^{*}$ & $0.71 \pm 0.3$ & $0.65 \pm 0.06^{*} \dagger$ & $1.37 \pm 0.3$ & $0.57 \pm 0.07 \dagger$ & $1.11 \pm 0.4$ \\
\hline & & & Low- $K^{+}$diet & & & & \\
\hline \multicolumn{8}{|c|}{ Male mice } \\
\hline Baseline & $3.7 \pm 0.7$ & $1.00 \pm 0.14$ & $0.59 \pm 0.1$ & $0.07 \pm 0.02^{\ddagger}$ & $0.66 \pm 0.1$ & $0.13 \pm 0.04^{\ddagger}$ & $14.16 \pm 5.7^{\ddagger}$ \\
\hline $0-30$ & $21.9 \pm 3.9^{*}$ & $1.05 \pm 0.09^{\ddagger}$ & $5.15 \pm 0.9^{* \star}$ & $0.22 \pm 0.05^{* \ddagger}$ & $5.37 \pm 1.0^{*}$ & $0.04 \pm 0.01^{\text {* }}$ & $25.38 \pm 4.2^{\ddagger}$ \\
\hline $30-60$ & $18.0 \pm 2.3^{* *}$ & $0.87 \pm 0.05^{\ddagger}$ & $4.39 \pm 0.6^{* \star}$ & $0.26 \pm 0.05^{* \ddagger}$ & $4.65 \pm 0.6^{* \ddagger}$ & $0.06 \pm 0.01^{\text {* }}$ & $19.63 \pm 3.6^{\ddagger}$ \\
\hline $60-90$ & $13.6 \pm 1.4^{* *}$ & $0.79 \pm 0.04^{\ddagger}$ & $3.42 \pm 0.3 * \ddagger$ & $0.28 \pm 0.04 *$ & $3.70 \pm 0.3^{* *}$ & $0.08 \pm 0.01^{*}$ & $14.09 \pm 3.1^{\ddagger}$ \\
\hline $90-120$ & $11.2 \pm 1.2^{* \ddagger}$ & $0.82 \pm 0.09^{\ddagger}$ & $2.82 \pm 0.3^{* \star}$ & $0.23 \pm 0.03 *$ & $3.05 \pm 0.3^{* *}$ & $0.08 \pm 0.01^{\text {* }}$ & $17.24 \pm 2.5^{\ddagger}$ \\
\hline \multicolumn{8}{|c|}{ Female mice } \\
\hline baseline & $4.4 \pm 0.4$ & $1.10 \pm 0.09$ & $1.09 \pm 0.2$ & $0.07 \pm 0.02^{\ddagger}$ & $1.16 \pm 0.2$ & $0.07 \pm 0.03^{\ddagger}$ & $20.13 \pm 4.1^{\ddagger}$ \\
\hline $0-30$ & $28.9 \pm 1.5^{*}$ & $1.14 \pm 0.11$ & $6.26 \pm 0.6^{*}$ & $0.20 \pm 0.06^{\ddagger}$ & $6.46 \pm 0.6^{*}$ & $0.03 \pm 0.01^{*}$ & $66.13 \pm 28.2^{\ddagger}$ \\
\hline $30-60$ & $25.2 \pm 1.3^{* *}$ & $0.84 \pm 0.09$ & $5.41 \pm 0.3^{* *}$ & $0.30 \pm 0.09 * *$ & $5.70 \pm 0.3^{* *}$ & $0.05 \pm 0.02^{\ddagger}$ & $39.00 \pm 15.5^{\ddagger}$ \\
\hline $60-90$ & $18.6 \pm 2.3^{* *}$ & $0.74 \pm 0.02 *$ & $3.93 \pm 0.5^{* \ddagger}$ & $0.34 \pm 0.09 * \$$ & $4.27 \pm 0.4^{* *}$ & $0.09 \pm 0.03^{\ddagger}$ & $20.51 \pm 7.2^{\ddagger}$ \\
\hline $90-120$ & $15.2 \pm 2.7 *{ }^{*}$ & $0.77 \pm 0.05^{* \ddagger}$ & $3.30 \pm 0.6^{* *}$ & $0.27 \pm 0.07 * \ddagger$ & $3.57 \pm 0.6^{* *}$ & $0.09 \pm 0.03^{\ddagger}$ & $18.69 \pm 6.3^{\ddagger}$ \\
\hline
\end{tabular}

Data are presented as means $\pm \mathrm{SE} ; n=6$ mice/group. Control- $\mathrm{K}^{+}$diet, diet contains $1 \% \mathrm{KCl}$; Low- $\mathrm{K}^{+}$diet, diet contains $0.1 \% \mathrm{~K}^{+} ; U V$, urine volume; GFR, glomerular filtration rate; $E_{N a}$, absolute excretion of $\mathrm{Na}^{+} ; E_{K}$, absolute excretion of $\mathrm{K}^{+} . E_{N a}+E_{K}$, total cation excretion; $E_{K} / E_{N a}+E_{K}$, fraction of $\mathrm{K}^{+}$from total cation excretion; $E_{N d} / E_{K}$, ratio of urine $\mathrm{Na}^{+}$and $\mathrm{K}^{+}$. ANOVA test was used to analyze significant difference among groups. $P<0.05$, significant difference from same group of animals in the control periods $(*)$, between sex in the same diet $(\dagger)$, and between CK and LK in the same sex $(\ddagger)$

\section{Western blot analysis}

Kidneys were homogenized with Mem-Plus Membrane Protein Extraction Reagent containing Halt protease inhibitor cocktail (Thermo Scientific, Rockford, IL). Protein concentration was determined by Bradford assay. Equal amounts $(25 \mu \mathrm{g})$ of protein samples were separated by SDSPAGE using $4-15 \%$ precast gels (Bio-Rad), transferred to nitrocellulose membranes and probed with antibodies against the following proteins: NCC (1:5000), a gift from Dr. 
Alicia McDonough, U. Southern California (37); phospho$\mathrm{Thr}^{53}$ NCC (1:1000) from Phosphosolutions, Cat\#: p131153); $\beta$-actin (1:5,000, from Sigma), NHE3 (3H3, 1:1000), a gift from Dr. Daniel Biemesderfer, Yale University (6); NHE2 (1:200) from Alomone Laboratories (Jerusalem, Israel); $\alpha, \beta$ and $\gamma \mathrm{ENaC}(1: 500)$ as described previously $(10,44,45)$; anti-NKCC2 (1:1000) from Chemicon Intl. The immune complexes were detected with Pierce ECL Western Blotting Substrate (Thermo Scientific). Bound complexes were visualized on autoradiography film (HyBlot CL, Denville Scientific) or with a Syngene PXi6 Gel and Blot Imaging System. Protein bands were quantified using ImageJ.

\section{Statistics}

Experimental data are presented as means \pm SE. At least 6 mice were contained in each group of renal clearance experiments, and 4 kidneys from 4 mice were contained in Western blotting experiments. Student's t-test was used to compare control and experimental groups. One-way ANOVA was used for comparison of multiple experimental groups with a control group followed by Dunnett's test. The difference between the mean values of an experimental group and a control group was considered significant if $\mathrm{P}<0.05$.

\section{Results}

\section{General phenotype of male and female mice fed with CK and LK diets}

Table 1 shows the body weight and plasma electrolyte of male and female mice fed with control $\mathrm{K}(\mathrm{CK}, 1 \% \mathrm{KCl})$ or low $\mathrm{K}(\mathrm{LK}, 0.1 \% \mathrm{KCl})$ diets. On CK diet, females had lower body weights than males, but these differences were not statistically significant. LK intake significantly reduced the body weight compared with the $\mathrm{CK}$ in females but not in males. $\mathrm{LK}$ intake did not change the plasma $\mathrm{Na}\left(\mathrm{P}_{\mathrm{Na}}\right)$ but significantly reduced plasma $\mathrm{K}\left(\mathrm{P}_{\mathrm{K}}\right)$ in both males and females. Under CK conditions, $\mathrm{P}_{\mathrm{K}}$ levels were slightly lower in females compared to the males but these differences were not statistically significant $(P>0.05)$. However, LK intake reduced $\mathrm{P}_{\mathrm{K}}$ to lower levels in females $(2.7 \mathrm{meq} / \mathrm{L})$ than in males $(3.3 \mathrm{meq} / \mathrm{L})(\mathrm{P}<0.05)$. Hematocrit was not different in males and females and was unchanged by LK intake.

\section{Effects of LK intake on thiazide-induced diuresis and natriuresis in male and female mice}

We measured responses to HCTZ by renal clearance. Baseline parameters were obtained from two 30-min collections of urine and blood. HCTZ (30 mg/kg) was given by intravenous bolus injection followed by four 30-min collections.
The time-dependent effects of HCTZ are shown in Figs. 1-4 and summarized in Table 2.

As shown in Fig. 1, HCTZ produced diuresis in all groups of mice. The diuretic effect reached a peak 30 min after the HCTZ bolus injection, and then gradually decreased toward baseline. Consistent with our earlier findings (18, 19), females fed with CK had a stronger diuretic response to HCTZ. With LK intake peak UV was not significantly changed, although the responses were more sustained. Baseline GFR was slightly higher in LK groups of both male and females $(P>0.05)$, and was significantly elevated after HCTZ administration.

Figure 2 shows HCTZ-induced natriuresis assessed as absolute $\left(\mathrm{E}_{\mathrm{Na}}\right)$ and fractional $\left(\mathrm{FE}_{\mathrm{Na}}\right) \mathrm{Na}$ excretion. Similar to our previous report $(18,19)$ in mice on CK the peak increments of $\mathrm{E}_{\mathrm{Na}}$ and $\mathrm{FE}_{\mathrm{Na}}$ were significantly higher in females than in males. LK intake increased HCTZ-dependent natriuresis more strongly in males than in females; in males, peak values of $\mathrm{E}_{\mathrm{Na}}$ doubled, while there was no significant change in females. Similar to the diuretic response, natriuresis was more sustained with $\mathrm{LK}$ in both sexes. Changes in $\mathrm{FE}_{\mathrm{Na}}$ showed the same pattern (Fig. $2 \mathrm{C}$ and D).

\section{Effects of LK intake on thiazide-induced kaliuresis in male and female mice}

Figure 3 shows HCTZ-induced kaliuresis. As expected, LK intake reduced baseline $\mathrm{E}_{\mathrm{K}}$ and $\mathrm{FE}_{\mathrm{K}}$ in both males and females. $E_{K}$ and $\mathrm{FE}_{\mathrm{K}}$ excretion significantly increased after HCTZ bolus injection in mice fed with CK. Similar to our previous reported $(18,19)$ in animals on CK the peak increments of $E_{K}$ and $\mathrm{FE}_{\mathrm{K}}$ after $\mathrm{HCTZ}$ administration were significantly higher in females (Fig. 3B and 3D) than that in males (Fig. 3A and 3C). With LK, despite a strong natriuresis, HCTZ increased $\mathrm{E}_{\mathrm{K}}$ and $\mathrm{FE}_{\mathrm{K}}$ only slightly $(\mathrm{P}<0.05)$ in all periods without a well-defined peak response. This suggests that the K-secreting machinery downstream of the DCT is suppressed under these conditions. Furthermore, differences between males and females disappeared.

\section{Effects of LK intake on thiazide-sensitive cation excretion in male and female mice}

Because some of the $\mathrm{Na}^{+}$that escapes the DCT when NCC is inhibited will be reabsorbed in downstream segments in exchange for $\mathrm{K}^{+}$, increased cation $\left(\mathrm{Na}^{+}+\mathrm{K}^{+}\right)$excretion may provide a more accurate assessment of the response to HCTZ. Figure 4A and 4B compare the effects of HCTZ on cation excretion between $\mathrm{CK}$ and LK in male and female mice, respectively. 4C and 4D compare male and female mice in CK and LK intake, respectively. Under LK conditions, HCTZ produced stronger increases in total cation excretion in male than in female mice (4A and $4 \mathrm{~B})$. As 
Fig. 4 Effect of HCTZ on total cation excretion $(\mathrm{ENa}+\mathrm{EK})$ in male and female mice fed with $\mathrm{CK}$ and $\mathrm{LK}$ diet. ENa + EK was measured before and after HCTZ iv bolus injection (until 90'). The peak change was observed 30' after HCTZ administration in all groups of the mice. $4 \mathrm{~A}$ and $4 \mathrm{~B}$ compare $\mathrm{CK}$ and $\mathrm{LK}$ in male (A) and female (B) mice. $4 \mathrm{C}$ and $4 \mathrm{D}$ compare male and female mice with CK (C) and LK (D) intake. Data are presented as means \pm SE. *: Significant difference from the baseline $(n=6$, $P<0.05$, by one-way ANOVA test); ${ }^{\ddagger}$ : Significant difference between CK and LK groups; \#: Significant difference between males and females fed with same diet $(n=6, P<0.05$, by one-way ANOVA test)
A
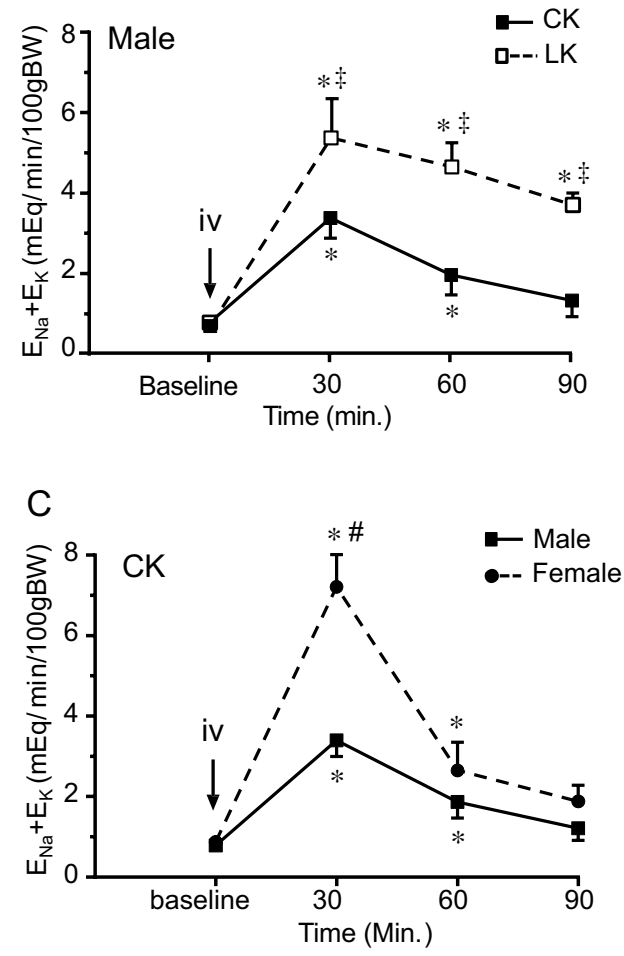

B

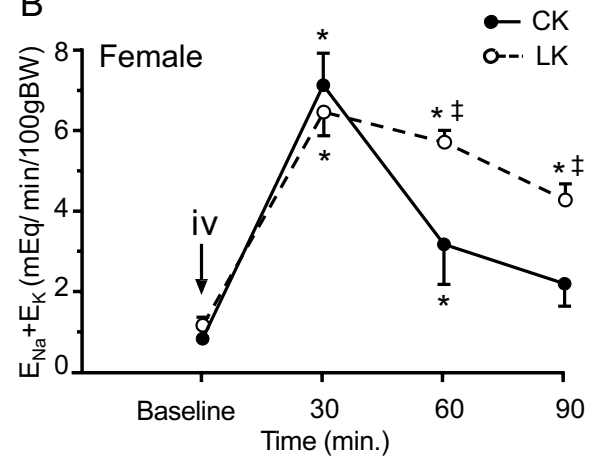

D

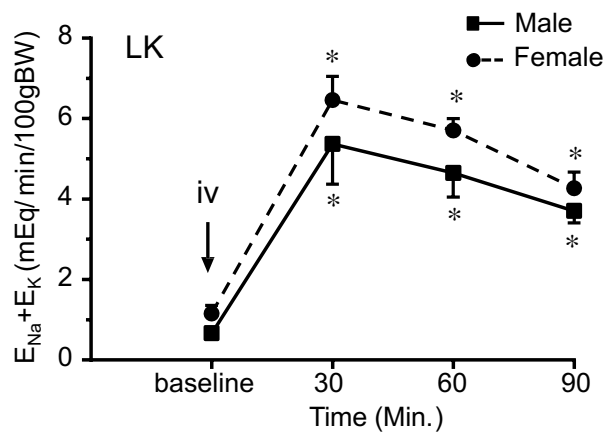

shown in Fig. 4C, HCTZ produced stronger increments of total cation excretion in females (Fig. 4C dotted line) than males (Fig. 4C, solid line) fed with CK diet, consistent with our previous findings (19). LK intake significantly increased the total cation excretion in males (Fig. 4D, solid line) but not in females (Fig. 4D, dotted line). The LK diet again abolished the sex-related difference in the diuretic response (Fig. 4D).

We also analyzed the ratio of urinary $\mathrm{Na}$ and $\mathrm{K}$ excretion $\left(\mathrm{E}_{\mathrm{Na}} / \mathrm{E}_{\mathrm{K}}\right)$. As shown in Table 2, with control diet blunting $\mathrm{NCC}$ activity increased $\mathrm{E}_{\mathrm{Na}}$ more than $\mathrm{E}_{\mathrm{K}}$, resulting in increased $\mathrm{E}_{\mathrm{Na}} / \mathrm{E}_{\mathrm{K}}$ in both male and females. This is consistent with the natriuretic effects of HCTZ. $\mathrm{E}_{\mathrm{Na}} / \mathrm{E}_{\mathrm{K}}$ is significantly higher with LK diet than with $\mathrm{CK}$ diet under all conditions due to the reduction of urinary $\mathrm{K}$ excretion and $\mathrm{K}$ intake. Although females have higher $\mathrm{E}_{\mathrm{Na}} / \mathrm{E}_{\mathrm{K}}$ after HCTZ than males, these differences did not reach statistical significance (Table 2).

\section{Effect of LK intake on NCC expression}

We next investigated sex differences in the modulation of total tNCC and pNCC expression by LK. NCC abundance was measured by Western blot in kidney tissues collected from mice treated with CK and LK diets for 7 days. Expression levels were normalized to $\beta$-actin and compared between male and female mice kidneys. As show in Fig. 5A and 5B females expressed higher levels of both tNCC and
pNCC than males when mice fed with CK. These findings agree with previously published work by our group and others $(29,37,38)$. LK intake doubled the levels of both tNCC and pNCC expression in males $(P<0.05)$ In female tNCC was increased by only $20 \%(P>0.05)$ while the pNCC was increased by $39 \%(P<0.05)$. These findings agree with our measurements of NCC activity by renal clearance and the greater reduction of plasma $\mathrm{K}$ in female mice fed with $\mathrm{LK}$ diet.

\section{Effect of LK intake on other Na transporters}

NHE3 is the predominant sodium-hydrogen exchanger in the apical membrane of the proximal tubule accounting for the major part of sodium and bicarbonate reabsorption in this segment, and also contributes to $\mathrm{Na}^{+}$transport in the thick ascending limb of Henle's loop $(4,40)$. Previously we demonstrated that $\mathrm{HK}$ intake reduced $\mathrm{Na} / \mathrm{H}$ exchanger (NHE3) expression in mouse kidney $(19,45)$. As shown in Fig. 6, NHE3 protein abundance was not changed in response to LK in either male or female mice.

NHE2 is the predominant $\mathrm{Na}-\mathrm{H}$ exchanger in the apical membranes of the distal tubule and the connecting tubules where it is contributes to $\mathrm{Na}^{+}$and $\mathrm{HCO}_{3}{ }^{-}$absorption (5, 40). We therefore examined NHE2 expression in male and female mice fed with CK and LK diets. As shown in Fig. 6, no significant differences were detected between LK and CK diets for either male or female mice. 
Fig. 5 Effect of LK intake on expression of NCC in mouse kidney. Kidneys were harvested from male and female mice fed with CK or LK diets for 7 days. A and B: Representative Western blots for tNCC and pNCC abundance. Blots were probed with anti-NCC, or antiphospho-Thr ${ }^{53}$ NCC. Staining with anti- $\beta$-actin served as a loading control. B: Densitometry values were normalized to the mean value for the CK mice. Data represent means \pm SE for four animals. *: Significant difference between CK and LK; \#: Significant difference between male and female $(p<0.05)$

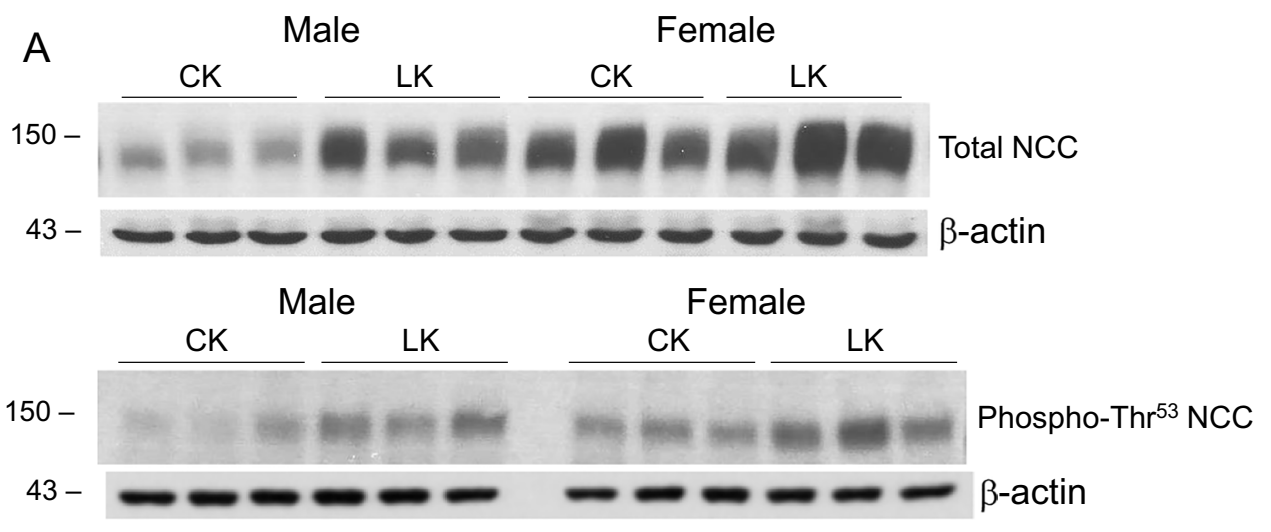

B

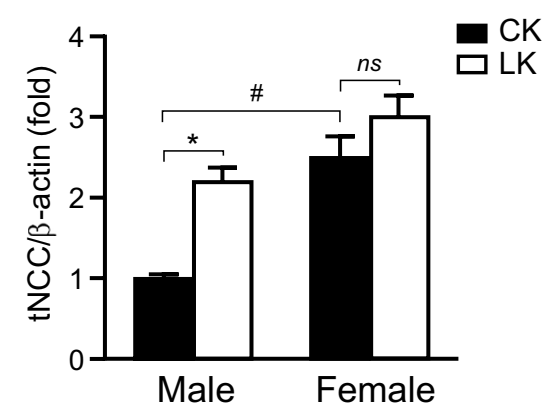

NKCC2 mediates reabsorption of both $\mathrm{Na}^{+}$and $\mathrm{K}^{+}$in the thick ascending limb of Henle's loop (1). To investigate the sex-dependence of this transporter in the adaptation to dietary $\mathrm{K}$ restriction we compared the abundance of $\mathrm{NKCC} 2$ protein in males and females on $\mathrm{CK}$ and $\mathrm{LK}$ diets. As shown in Fig. 6, males on a LK diet had a small $(30 \%)$ decrease in NKCC2 abundance, although this change was not statistically significant $(p=0.13)$. Expression in females did not change.

\section{Effect of LK intake on ENaC expression}

The epithelial $\mathrm{Na}$ channel $(\mathrm{ENaC})$ plays a critical role in $\mathrm{K}$ homeostasis by creating a driving force for $\mathrm{K}^{+}$secretion in the CNT and CCD. The LK diet reduced the abundance of the cleaved, presumably active forms (17) of $\alpha \mathrm{ENaC}$ and $\gamma \mathrm{ENaC}$ (Fig. 7). In the case of $\gamma \mathrm{ENaC}$ we detected two cleaved forms of the protein, likely corresponding to furin-cleaved and twice-cleaved species (14). For both subunits the fractional decrease was somewhat larger in males, and for $\alpha \mathrm{ENaC}$ it was statistically significant only in males. We detected no changes in the abundance of $\beta \mathrm{ENaC}$. These effects are consistent with a reduction in plasma aldosterone in LK-fed animals, although this was not measured.

\section{Discussion}

We investigated the sex differences in adaptation to LK intake. Mice adapted to a low-K diet have increased NCC function as assessed by HCTZ-induced diuresis and natriuresis. This corroborates previous studies reporting that restricting $\mathrm{K}^{+}$intake increased the expression of NCC protein in rats and mice $(11,32,39)$. Here we show that increases in both function and expression of NCC were more robust, while decreases in plasma $\mathrm{K}^{+}$were smaller, in males than in females. This is the converse of the responses to increased $\mathrm{K}^{+}$intake, which decreased NCC function and expression in both male and female mice (19). LK did not change the expression of other ion transporters (NHE3, NHE2, and NKCC2).

The enhanced NCC function, together with decreased $\mathrm{ENaC}$ activity inferred from reduced abundance of the cleaved form of the $\alpha$ and $\gamma$ subunits, would shift $\mathrm{Na}^{+}$ reabsorption from the CNT, where it is in part exchanged for $\mathrm{K}^{+}$, to the DCT, where it is reabsorbed along with $\mathrm{Cl}^{-}$. The overall effect will reduce $\mathrm{K}^{+}$excretion in the face of reduced dietary intake. Reduction in ROMK channel activity, in part secondary to activation of protein tyrosine kinases (41) will also contribute to $\mathrm{K}^{+}$conservation under these conditions. These responses are opposite 

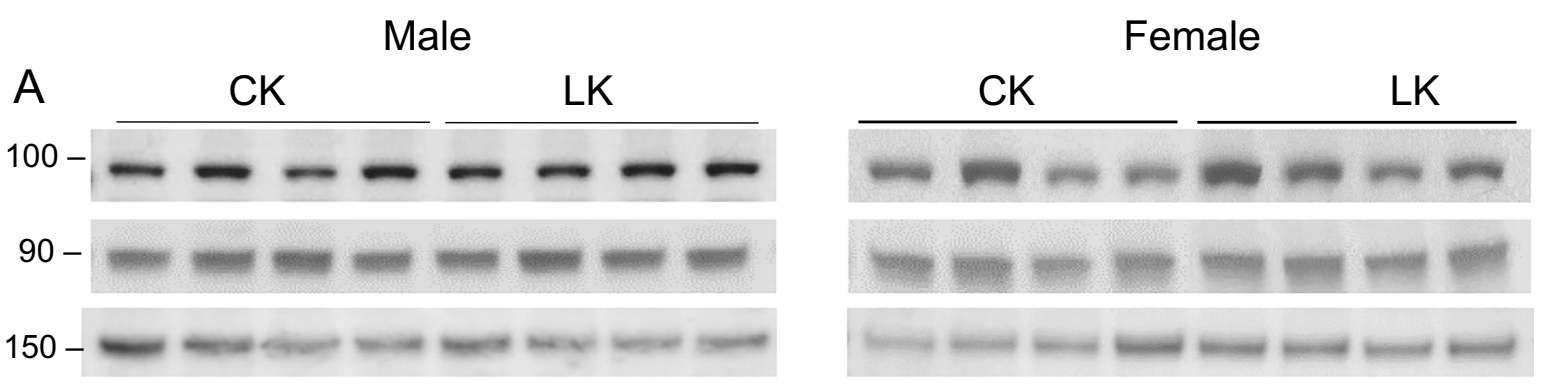

NHE3

NHE2

$\mathrm{B}$
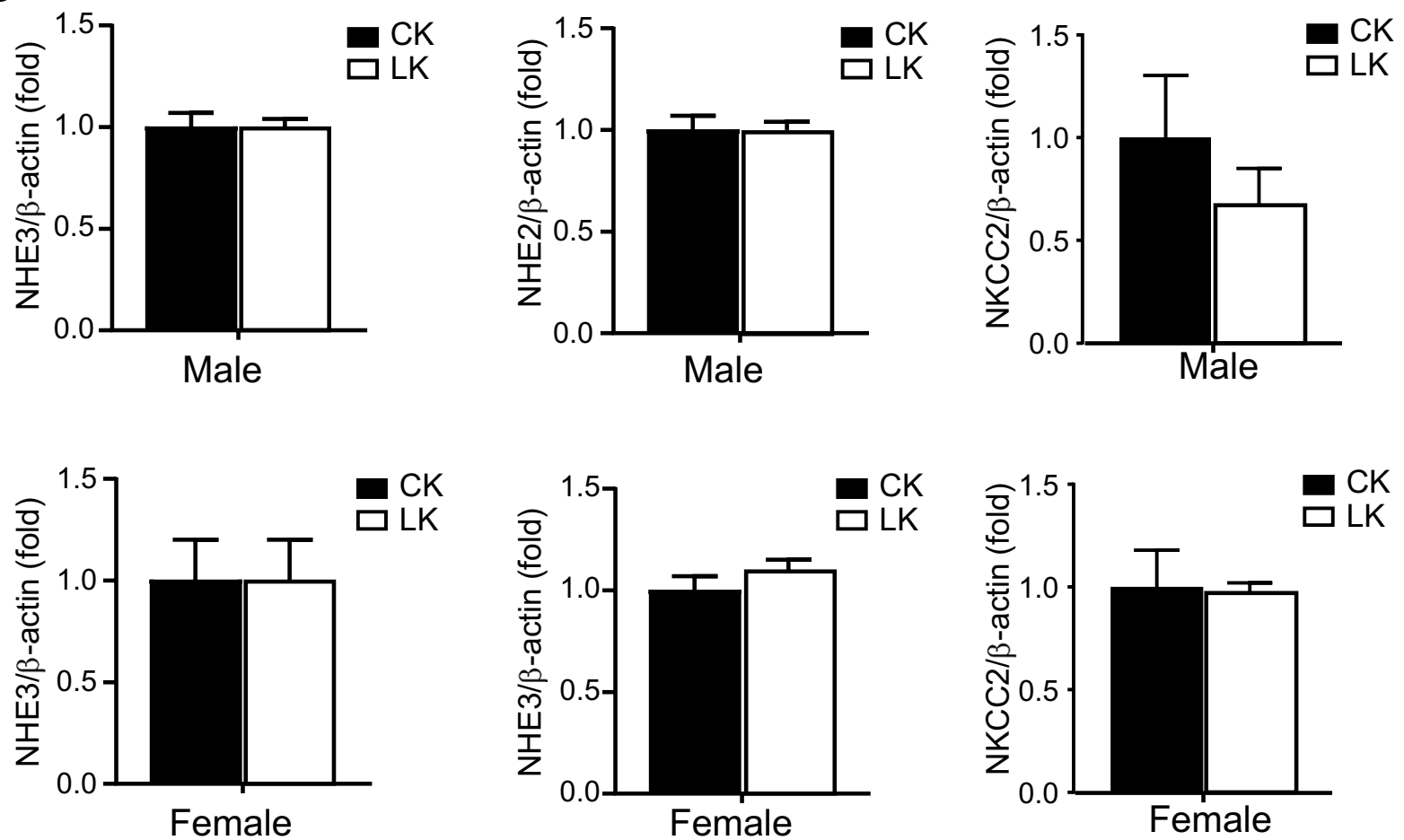

Fig. 6 Effects of LK intake on expression of NHE3, NHE2, and NKCC2 in mouse kidney. NHE3, NHE2, and NKCC2 protein expression in male and female mice fed with control-K (CK) or low-K (LK) diets for 7 days. A: Representative Western blots for proteins abundance. Blots were stained with anti-NHE3 (3H3, 1:1000), NHE2

to those observed with elevated $\mathrm{K}^{+}$intake. In that case $\mathrm{NCC}$ expression decreases, while that of cleaved $\mathrm{ENaC}$ increases $(12,45)$. One difference is that in the case of $\mathrm{HK}$ intake there is also evidence for decreases in $\mathrm{Na}^{+}$ reabsorption in more proximal segments. HK reduces NHE3 protein expression in the mouse $(19,45)$. In the case of LK, changes in transporter protein expression were restricted to NCC, with no significant changes in NHE3, NHE2, or NKCC2.

In this study, the LK diet increased HCTZ-sensitive $\mathrm{Na}^{+}$transport in males, to the point where it was approximately equal to that of females. Since both are presumably in $\mathrm{Na}^{+}$balance, this suggests that DCT $\mathrm{Na}^{+}$delivery in males increased to become comparable to that of females.
(Alomone, 1:200), and NKCC2 (Chemicon, 1:1000). B: Densitometry values were normalized to the mean value for the CK mice. Data represent means $\pm \mathrm{SE}$ for four animals. No significant differences between LK and CK diets were detected

Alternatively, there could have been a much more marked down-regulation of the aldosterone-sensitive distal nephron in males, but there is nothing in the observed $\mathrm{ENaC}$ response to suggest this. In light of our prior observation that an HK diet increased distal $\mathrm{Na}^{+}$delivery in male mice (19), it seems paradoxical that in this study LK also appears to increase distal $\mathrm{Na}^{+}$delivery, at least as appreciated in the greater thiazide-induced cation excretion (ENa + EK in Table 2). With HK, a reduction in NHE3 abundance was held accountable; with LK, the etiology is less certain. In LK, the increase in distal $\mathrm{Na}^{+}$delivery may derive in part from an increase in GFR (Table 2). The mechanism underlying this increased filtration has not been examined here, but it appears consistent with the observation that the action of tubuloglomerular 


\section{Male}

\section{Female}

A

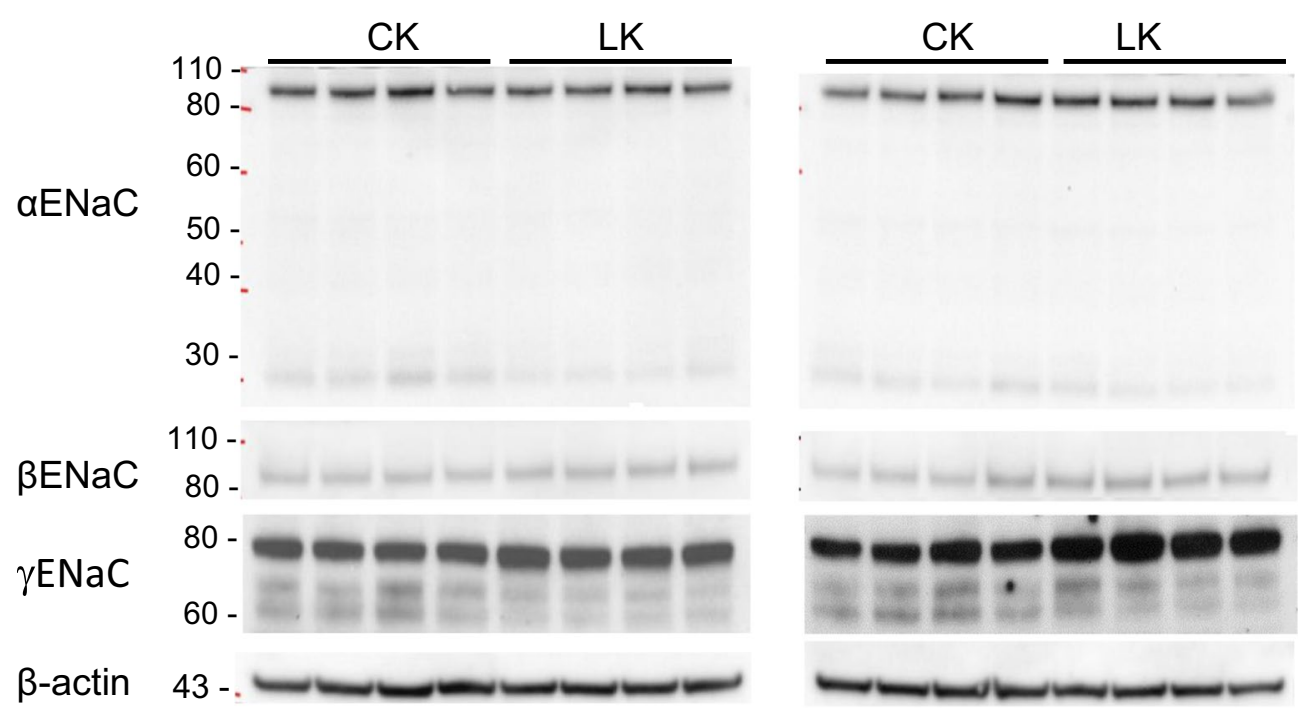

B
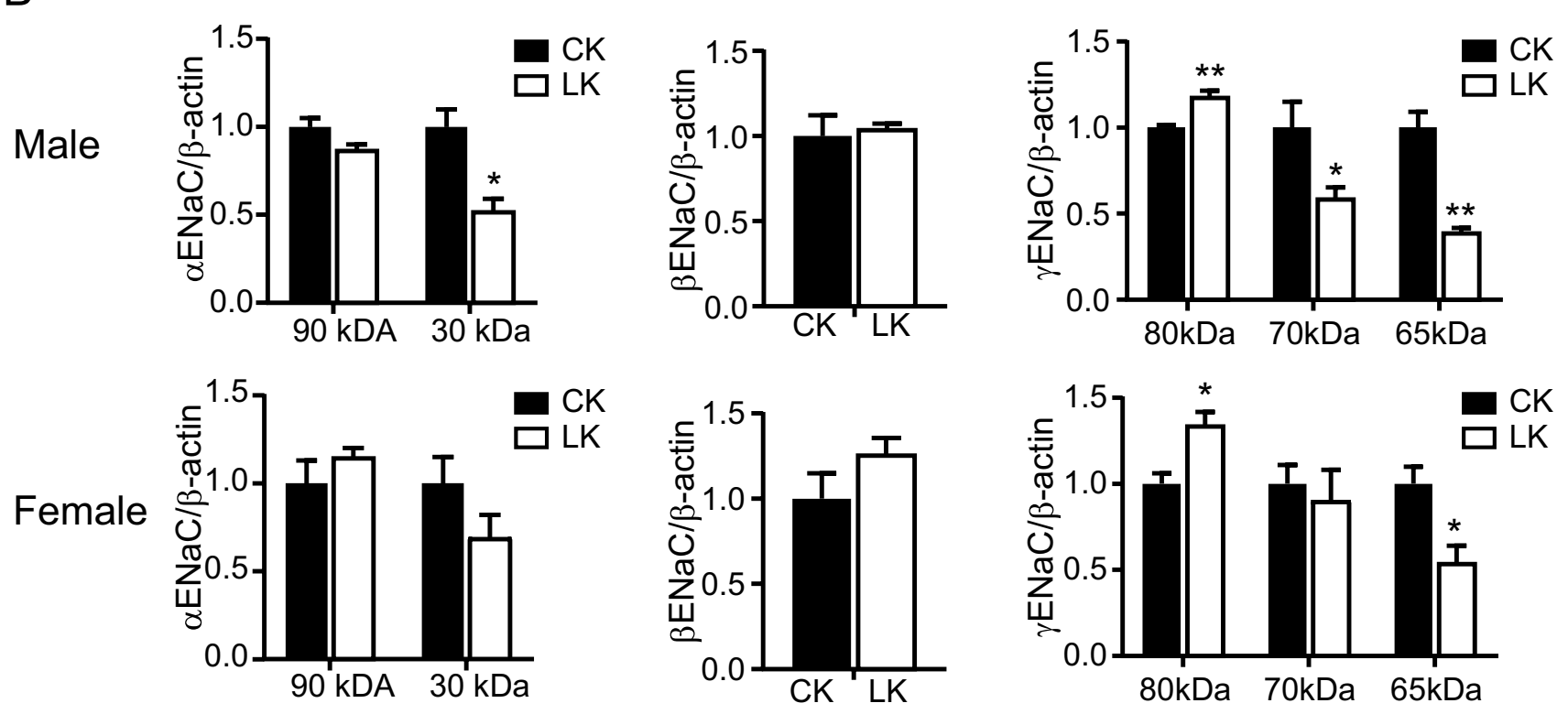

Fig. 7 Effects of LK intake on expression of $\alpha, \beta$, and $\gamma \mathrm{ENaC}$ in male and female mice kidney. A: Western blots of $\alpha, \beta$, and $\gamma \mathrm{ENaC}$ protein abundance in male and female mice fed with CK or LK diets for 7 days. B: Densitometry values were normalized to the mean value for the CK mice. Data represent means \pm SE for four animals. Significant differences between CK and LK, $* P<0.05 ; * * P<0.01$ feedback to reduce SNGFR is blunted by low luminal $\mathrm{K}^{+}$ (34). Although acute hypokalemia should enhance proximal tubule $\mathrm{Na}^{+}$reabsorption (2), the chronic situation may be different. Malnic et al. (20) displayed tubule-fluid-to-plasma$\mathrm{K}^{+}$flows $\left(\mathrm{TF} / \mathrm{PK}^{+}\right)$as a function of distance along the $\mathrm{PT}$, for controls and for hypokalemic male rats (their Figs. 3 and 4), and the more shallow slope of the hypokalemic rats suggests reduced proximal fluid reabsorption. Moving distally, there is the observation in the intact rat, that hypokalemia diminishes maximal free-water clearance, i.e., blunts solute reabsorption by thick AHL (7). With an increase in GFR and reduced tubular $\mathrm{Na}^{+}$reabsorption, it is possible to rationalize increased DCT Na${ }^{+}$delivery on the LK diet. This increased delivery would be a luminal signal to increase DCT reabsorption, acting in conjunction with the peritubular signal of hypokalemia.

As shown previously, females have a higher NCC expression than males, and these differences depend on female hormones $(29,38)$. Although females express more NCC and have greater HCTZ-dependent natriuresis when animals are on a CK diet, the differences between the sexes disappear when the mice are fed with either LK (Fig. 2) or HK 

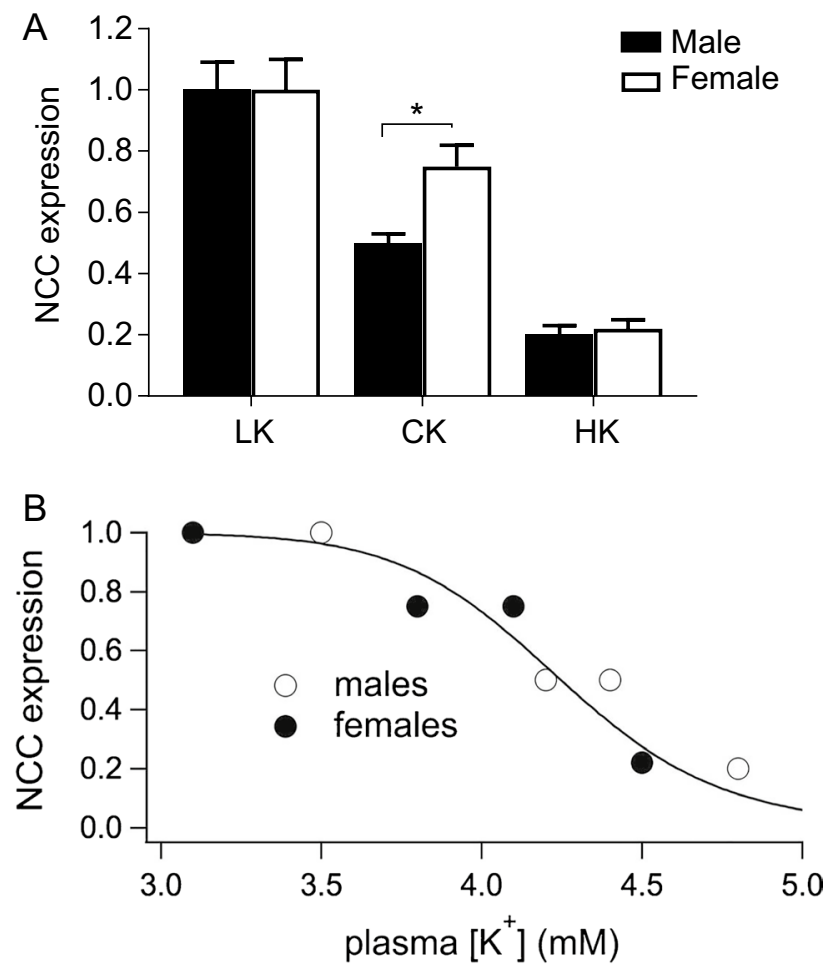

Fig. $8 \mathrm{~K}^{+}$- dependent changes in NCC expression in male and female mice. A. Relationships between $\mathrm{K}$ intake and NCC expression. Increasing dietary $\mathrm{K}^{+}$intake decreases $\mathrm{NCC}$ expression at lower levels in males than females. B. Relationship between plasma $\mathrm{K}^{+}$and NCC activity. Data from males and females fall on the same curve. The solid line is a best-fit to the equation: $\mathrm{NCC} / \mathrm{NCC}_{\max }=1 /(1+([\mathrm{K}] /$ $\left.[\mathrm{K}]_{1 / 2}\right)^{\mathrm{n}}$ ) where $[\mathrm{K}]_{1 / 2}=4.2 \mathrm{mM}$ and $n=17$

(19) diet. This implies that the inverse relationship between $\mathrm{K}^{+}$intake and NCC activity shifts toward higher levels of intake in females (Fig. 8A). Because the DCT cells can respond directly to extracellular $\mathrm{K}^{+}(26,32)$, this raises the possibility that sex differences arise from a similar shift in the relationship between plasma $\mathrm{K}^{+}$and NCC. Figure 8.B, shows the expression of total NCC as a function of measured plasma $\left[\mathrm{K}^{+}\right]$in control, K-loaded and K-depleted mice. Previous results showed parallel changes in total and phosphorylated NCC under chronic conditions $(32,45)$. The data from male and female mice appear to fall on the same curve with a sharply negative slope in the physiological range, indicating that the intrinsic relationships between NCC and $\left[\mathrm{K}^{+}\right]$are similar.

This suggests that the greater expression of NCC in females could be secondary to decreased plasma $\left[\mathrm{K}^{+}\right]$. In our experiments females generally had lower $\left[\mathrm{K}^{+}\right]$levels, although the differences were statistically significant only in animals on LK. However, the trend was similar in all groups including mice on a HK diet reported previously (19). Normalizing data to mean values in males for each condition, we estimate a $10 \%$ decrease in plasma $\mathrm{K}^{+}$in females vs. males that is highly significant $(p=0.01, n=19)$. Previous studies in rats also documented lower plasma $\left[\mathrm{K}^{+}\right]$in females $(23$, 47) even without controlling for possible variations within the estrus cycle. Because increased NCC activity by itself should increase plasma $\left[\mathrm{K}^{+}\right]$, these findings support the idea that the sex-dependent differences in NCC expression result from variation in plasma $\left[\mathrm{K}^{+}\right]$, rather than causing them. This raises the question of what parts of the nephron are primarily responsible for the altered set-point for $\mathrm{K}^{+}$homeostasis. The $\mathrm{K}^{+}$-secreting segments such as the $\mathrm{CNT}$, are one possibility with $\mathrm{ENaC}$ being an important determinant of $\mathrm{K}^{+}$secretion $(13,42)$. We found no strong sex differences in $\mathrm{ENaC}$ protein expression in mouse kidney, in agreement with previous studies $(18,19)$. In rat kidneys ENaC expression was significantly higher in females, although the differences were small (37). Variation in proximal tubule $\mathrm{Na}^{+}$ reabsorption could also contribute to the altered set points. We found no differences in NHE3 expression, in agreement with previous findings $(18,19,37)$. However, Veiras et al. (37) reported that female rats have decreased proximal tubule $\mathrm{HCO}_{3}{ }^{-}$reabsorption and increased $\mathrm{Li}^{+}$clearance, both indicative of reduced NHE3-mediated transport. This finding was consistent with their observation that female rats showed greater concentration of NHE3 at the microvilli base, suggesting that these transporters were not active. This would increase both $\mathrm{Na}^{+}$and volume delivery to the distal nephron, driving increased $\mathrm{K}^{+}$secretion even more strongly than comparable changes in NCC activity (45). Whether the female reproductive hormones that drive these changes act directly on these nephron segments, or on other endocrine systems such as the renin-angiotensin-aldosterone axis, remains to be established.

Our finding that females rely more heavily on distal nephron Na reabsorption than do males, is consistent with observations of others, and raises the question of how this relates to sex-specific "baseline" serum $\mathrm{K}^{+}$concentrations. McDonough's group reported that the distal nephrons of females had a higher abundance of total and phosphorylated NCC, which was associated with lower baseline plasma $\mathrm{K}^{+}$concentration in rats (37). Previous studies have also reported plasma $\mathrm{K}^{+}$is lower in female rats than males (22) and this difference is dependent on estrogen levels, since ovariectomy raised plasma $\mathrm{K}^{+}$, which was reduced by estrogen replacement in rats $(22,27)$. We have also found lower baseline plasma $\mathrm{K}^{+}$in female mice ((18) and Table 1), although this observation is not universal (46). In a large United States-based population study, there was lower serum potassium for all age groups of females compared with males (43). Since hypokalemia affects millions of persons (especially young women) in the US, it has been suggested that extra care is needed for women who may be susceptible to hypokalemia, either by virtue of an eating disorder or gastrointestinal disturbance, or from medication (43). The 
possible significance of mild hypokalemia is underscored in a prospective Dutch population-based study, which found that hypokalemia was associated with an increased chronic kidney disease (CKD) risk (16). The mechanistic connection between lower baseline $\mathrm{K}^{+}$and greater reliance on distal nephron $\mathrm{Na}^{+}$reabsorption may be viewed from the perspective of both cause and effect. The impact of hypokalemia to shift $\mathrm{Na}^{+}$reabsorption distally has become a secure finding. What this study contributes to this discussion is the observation that females may have a reduced capacity to defend against hypokalemia, by minimizing $\mathrm{Na}^{+}$delivery to K-secretory nephron segments.

In summary the major new observations of this study are that LK intake produced a more robust increase in both NCC expression and in NCC activity in males than in female mice. As a result LK intake abolished the sex differences observed under CK conditions. LK also produced less reduction of plasma $\mathrm{K}^{+}$in males than in females. These results support the conclusion that males have a stronger NCC-mediated adaptation to LK intake than females.

Acknowledgements This work was supported by NIH grants RO1DK099284 (TW and LP), R01 DK117650 (TW) and RO1- DK-29857 (AW). We thank Drs. Daniel Biemesdorfer and Alicia McDonough for gifts of antibodies

Open Access This article is licensed under a Creative Commons Attribution 4.0 International License, which permits use, sharing, adaptation, distribution and reproduction in any medium or format, as long as you give appropriate credit to the original author(s) and the source, provide a link to the Creative Commons licence, and indicate if changes were made. The images or other third party material in this article are included in the article's Creative Commons licence, unless indicated otherwise in a credit line to the material. If material is not included in the article's Creative Commons licence and your intended use is not permitted by statutory regulation or exceeds the permitted use, you will need to obtain permission directly from the copyright holder. To view a copy of this licence, visit http://creativecommons.org/licenses/by/4.0/.

\section{References}

1. Bazúa-Valenti S, Castañeda-Bueno M, Gamba G (2016) Physiological role of SLC12 family members in the kidney. Am J Physiol Renal Physiol 311:F131-144

2. Brandis M, Keyes J, Windhager EE (1972) Potassium-induced inhibition of proximal tubular fluid reabsorption in rats. Am J Physiol 222:421-427

3. Cantone A, Yang X, Yan Q, Giebisch G, Hebert SC, Wang T (2008) Mouse model of type II Bartter's syndrome. I. Upregulation of thiazide-sensitive Na-Cl cotransport activity. Am J Physiol Renal Physiol 294:F1366-1372

4. Capasso G, Unwin R, Agulian S, Giebisch G (1991) Bicarbonate transport along the loop of Henle. I. Microperfusion studies of load and inhibitor sensitivity. J Clin Invest 88:430-437

5. Chambrey R, Warnock DG, Podevin RA, Bruneval P, Mandet C, Belair MF, Bariety J, Paillard M (1998) Immunolocalization of the $\mathrm{Na}+/ \mathrm{H}+$ exchanger isoform NHE2 in rat kidney. Am J Physiol 275:F379-386

6. Duan Y, Weinstein AM, Weinbaum S, Wang T (2010) Shear stress-induced changes of membrane transporter localization and expression in mouse proximal tubule cells. Proc Natl Acad Sci U S A 107:21860-21865

7. Eknoyan G, Martinez-Maldonado M, Suki WN, Richie Y (1970) Renal diluting capacity in the hypokalemic rat. Am J Physiol 219:933-937

8. Ellison DH (2003) The thiazide-sensitive na-cl cotransporter and human disease: reemergence of an old player. J Am Soc Nephrol 14:538-540

9. Ellison DH, Terker AS, Gamba G (2016) Potassium and Its Discontents: New Insight, New Treatments. J Am Soc Nephrol 27:981-989

10. Ergonul Z, Frindt G, Palmer LG (2006) Regulation of maturation and processing of ENaC subunits in the rat kidney. Am J Physiol Renal Physiol 291:F683-693

11. Frindt G, Houde V, Palmer LG (2011) Conservation of Na+ versus $\mathrm{K}+$ by the rat cortical collecting duct. Am J Physiol Renal Physiol 301:F14-F20

12. Frindt G, Palmer LG (2010) Effects of dietary K on cell-surface expression of renal ion channels and transporters. Am J Physiol Renal Physiol 299:F890-897

13. Frindt G, Shah A, Edvinsson J, Palmer LG (2009) Dietary K regulates ROMK channels in connecting tubule and cortical collecting duct of rat kidney. Am J Physiol Renal Physiol 296:F347-354

14. Frindt G, Shi S, Kleyman TR, Palmer LG (2021) Cleavage state of $\gamma \mathrm{ENaC}$ in mouse and rat kidneys. Am J Physiol Renal Physiol 320:F485-f491

15. Gamba G (2009) The thiazide-sensitive Na+-Cl- cotransporter: molecular biology, functional properties, and regulation by WNKs. Am J Physiol Renal Physiol 297:F838-848

16. Kieneker LM, Eisenga MF, Joosten MM, de Boer RA, Gansevoort RT, Kootstra-Ros JE, Navis G, Bakker SJ (2017) Plasma potassium, diuretic use and risk of developing chronic kidney disease in a predominantly White population. PloS one 12:e0174686

17. Kleyman TR, Carattino MD, Hughey RP (2009) ENaC at the cutting edge: regulation of epithelial sodium channels by proteases. J Biol Chem 284:20447-20451

18. Li J, Hatano R, Xu S, Wan L, Yang L, Weinstein AM, Palmer L, Wang T (2017) Gender difference in kidney electrolyte transport. I. Role of AT1a receptor in thiazide-sensitive $\mathrm{Na}(+)-\mathrm{Cl}(-)$ cotransporter activity and expression in male and female mice. Am J Physiol Renal Physiol 313:F505-F513

19. Li J, Xu S, Yang L, Yang J, Wang CJ, Weinstein AM, Palmer LG, Wang T (2019) Sex difference in kidney electrolyte transport II: impact of $\mathrm{K}(+)$ intake on thiazide-sensitive cation excretion in male and female mice. Am J Physiol Renal Physiol 317:F967-F977

20. Malnic G, Klose RM, Giebisch G (1964) Micropuncture study of renal potassium excretion in the rat. Am J Physiol 206:674-686

21. Moes AD, van der Lubbe N, Zietse R, Loffing J, Hoorn EJ (2014) The sodium chloride cotransporter SLC12A3: new roles in sodium, potassium, and blood pressure regulation. Pflugers Arch 466:107-118

22. Nachbaur J, Clarke M, Provost J, Dancla J (1977) Variations of sodium, potassium, and chloride plasma levels in the rat with age and sex. Lab Anim Sci 27:972-975

23. Nachbaur J, Clarke MR, Provost JP, Dancla JL (1977) Variations of sodium, potassium, and chloride plasma levels in the rat with age and sex. Lab Anim Sci 27:972-975

24. Pacheco-Alvarez D, Cristobal PS, Meade P, Moreno E, Vazquez N, Munoz E, Diaz A, Juarez ME, Gimenez I, Gamba G (2006) The $\mathrm{Na}+\mathrm{Cl}-$ cotransporter is activated and phosphorylated at the 
amino-terminal domain upon intracellular chloride depletion. J Biol Chem 281:28755-28763

25. Pedersen NB, Hofmeister MV, Rosenbaek LL, Nielsen J, Fenton RA (2010) Vasopressin induces phosphorylation of the thiazidesensitive sodium chloride cotransporter in the distal convoluted tubule. Kidney Int 78:160-169

26. Penton D, Czogalla J, Wengi A, Himmerkus N, Loffing-Cueni D, Carrel M, Rajaram RD, Staub O, Bleich M, Schweda F, and Loffing J (2016) Extracellular K+ rapidly controls NaCl cotransporter phosphorylation in the native distal convoluted tubule by Cl- -dependent and independent mechanisms. J Physiol

27. Riazi S, Maric C, Ecelbarger CA (2006) 17-beta Estradiol attenuates streptozotocin-induced diabetes and regulates the expression of renal sodium transporters. Kidney Int 69:471-480

28. Rinehart J, Kahle KT, de Los HP, Vazquez N, Meade P, Wilson FH, Hebert SC, Gimenez I, Gamba G, Lifton RP (2005) WNK3 kinase is a positive regulator of NKCC2 and NCC, renal cationCl- cotransporters required for normal blood pressure homeostasis. Proc Natl Acad Sci U S A 102:16777-16782

29. Rojas-Vega L, Reyes-Castro LA, Ramirez V, Bautista-Perez R, Rafael C, Castaneda-Bueno M, Meade P, de Los HP, ArroyoGarza I, Bernard V, Binart N, Bobadilla NA, Hadchouel J, Zambrano E, Gamba G (2015) Ovarian hormones and prolactin increase renal $\mathrm{NaCl}$ cotransporter phosphorylation. Am J Physiol Renal Physiol 308:F799-808

30. Sorensen MV, Grossmann S, Roesinger M, Gresko N, Todkar AP, Barmettler G, Ziegler U, Odermatt A, Loffing-Cueni D, Loffing J (2013) Rapid dephosphorylation of the renal sodium chloride cotransporter in response to oral potassium intake in mice. Kidney Int 83:811-824

31. Subramanya AR, Ellison DH (2014) Distal convoluted tubule. Clin J Am Soc Nephrol 9:2147-2163

32. Terker AS, Zhang C, Erspamer KJ, Gamba G, Yang CL, Ellison DH (2016) Unique chloride-sensing properties of WNK4 permit the distal nephron to modulate potassium homeostasis. Kidney Int 89:127-134

33. Terker AS, Zhang C, McCormick JA, Lazelle RA, Zhang C, Meermeier NP, Siler DA, Park HJ, Fu Y, Cohen DM, Weinstein AM, Wang WH, Yang CL, Ellison DH (2015) Potassium modulates electrolyte balance and blood pressure through effects on distal cell voltage and chloride. Cell Metab 21:39-50

34. Vallon V, Osswald H, Blantz RC, Thomson S (1997) Potential role of luminal potassium in tubuloglomerular feedback. J Am Soc Nephrol 8:1831-1837

35. van der Lubbe N, Lim CH, Fenton RA, Meima ME, Jan Danser AH, Zietse R, Hoorn EJ (2011) Angiotensin II induces phosphorylation of the thiazide-sensitive sodium chloride cotransporter independent of aldosterone. Kidney Int 79:66-76

36. van der Lubbe N, Moes AD, Rosenbaek LL, Schoep S, Meima ME, Danser AH, Fenton RA, Zietse R, Hoorn EJ (2013)
$\mathrm{K}+$-induced natriuresis is preserved during $\mathrm{Na}+$ depletion and accompanied by inhibition of the Na+-Cl- cotransporter. Am J Physiol Renal Physiol 305:F1177-1188

37. Veiras LC, Girardi ACC, Curry J, Pei L, Ralph DL, Tran A, Castelo-Branco RC, Pastor-Soler N, Arranz CT, Yu ASL, McDonough AA (2017) Sexual Dimorphic Pattern of Renal Transporters and Electrolyte Homeostasis. J Am Soc Nephrol 28:3504-3517

38. Verlander JW, Tran TM, Zhang L, Kaplan MR, Hebert SC (1998) Estradiol enhances thiazide-sensitive $\mathrm{NaCl}$ cotransporter density in the apical plasma membrane of the distal convoluted tubule in ovariectomized rats. J Clin Invest 101:1661-1669

39. Wade JB, Liu J, Coleman R, Grimm PR, Delpire E, Welling PA (2015) SPAK-mediated NCC regulation in response to low-K+ diet. Am J Physiol Renal Physiol 308:F923-931

40. Wang T, Hropot M, Aronson PS, Giebisch G (2001) Role of NHE isoforms in mediating bicarbonate reabsorption along the nephron. Am J Physiol Renal Physiol 281:F1117-1122

41. Wang W, Lerea KM, Chan M, Giebisch G (2000) Protein tyrosine kinase regulates the number of renal secretory K channels. Am J Physiol 278:F165-F171

42. Weinstein AM (2005) A mathematical model of rat distal convoluted tubule. II. Potassium secretion along the connecting segment. Am J Physiol Renal Physiol 289:F721-741

43. Wysowski DK, Kornegay C, Nourjah P, Trontell A (2003) Sex and age differences in serum potassium in the United States. Clin Chem 49:190-192

44. Yang L, Frindt G, Lang F, Kuhl D, Vallon V, Palmer LG (2017) SGK1-dependent ENaC processing and trafficking in mice with high dietary $\mathrm{K}$ intake and elevated aldosterone. Am J Physiol Renal Physiol 312:F65-F76

45. Yang L, Xu S, Guo X, Uchida S, Weinstein AM, Wang T, Palmer LG (2018) Regulation of renal Na transporters in response to dietary K. Am J Physiol Renal Physiol 315:F1032-F1041

46. Yu G, Cheng M, Wang W, Zhao R, Liu Z (2017) Involvement of WNK1-mediated potassium channels in the sexual dimorphism of blood pressure. Biochem Biophys Res Commun 485:255-260

47. Zheng W, Shi M, You SE, Ji H, Roesch DM (2006) Estrogens contribute to a sex difference in plasma potassium concentration: a mechanism for regulation of adrenal angiotensin receptors. Gend Med 3:43-53

48. Zhou B, Zhuang J, Gu D, Wang H, Cebotaru L, Guggino WB, Cai H (2010) WNK4 enhances the degradation of NCC through a sortilin-mediated lysosomal pathway. J Am Soc Nephrol 21:82-92

Publisher's note Springer Nature remains neutral with regard to jurisdictional claims in published maps and institutional affiliations. 